\title{
KARAKTERISTIK DAN POLA PERJALANAN WISATAWAN BACKPACKER YANG MENGINAP DI CANGGU, BADUNG
}

\author{
Cening Suprani Gama ${ }^{1}$, I Putu Sudana ${ }^{2}$, Luh Gede Leli Kusuma Dewi ${ }^{3}$ \\ Email': ceninggama01@gmail.com \\ Program Studi Industri Perjalanan Wisata, Fakultas Pariwisata, Universitas Udayana \\ Email ${ }^{2}$ : sudanaputu@yahoo.com \\ Program Studi Industri Perjalanan Wisata, Fakultas Pariwisata, Universitas Udayana \\ Email $^{3}$ : leli_ipw@unud.ac.id \\ Program Studi Industri Perjalanan Wisata, Fakultas Pariwisata, Universitas Udayana
}

\begin{abstract}
Canggu is one of the the most visited areas by backpacker tourists viewed by the amount of hostel accommodations. This study aims to determine the characteristics and travel patterns of backpacker tourists who stay in Canggu. The sample of this research is backpacker tourists staying at Canggu, determining the sample using purposive and quota sampling on 132 respondents. Data obtained in several ways, such as: observation, questionnaires, literature study, and documentation. Quantitative descriptive and qualitative descriptive were used to analyse the data result. The results showed that backpacker tourists take an intra-destination travel pattern, which is to travel in Bali, the most visited tourist destination in Bali is Ubud with an average stay of 6 days, dominantly making an intra-destination travel pattern; Ubud-Uluwatu- Canggu, and Kuta as the first tourist destination visited in Bali. Inter-destination travel patterns, while travel between destinations in Indonesia, most backpacker tourists visit Gili Island with an average stay of 5 days, dominantly doing inter-destination travel patterns such as Gili Island-Bali, and Bali as a tourist destination first visited. Intra-regional patterns, as trips made in Southeast Asian countries, Thailand was most visited by backpacker tourists other than Indonesia, dominantly carried out intra-regional travel patterns like Thailand-CambodiaVietnam-Indonesia, and Indonesia as first destination visited. Inter-regional patterns, backpacker tourists also visit other countries other than Southeast Asia, and predominantly visit Australia with an average stay of 91 days, and do inter-regional travel patterns that is Australia- ASEAN, and the ASEAN region being the first destination visited.
\end{abstract}

Abstrak: Canggu menjadi salah satu kawasan yang banyak dikunjungi oleh wisatawan backpacker ditandai dengan banyaknya akomodasi hostel. Studi ini bertujuan untuk mengetahui karakteristik dan pola perjalanan wisatawan backpacker yang menginap di Canggu. Sampel yang diteliti yaitu wisatawan backpacker yang menginap di Canggu, dengan penentuan sampel menggunakan purposive dan quota sampling pada 132 orang responden. Data diperoleh dengan beberapa cara, diantaranya: observasi, kuesioner, studi kepustakaan, dan dokumentasi. Teknik analisis data dilakukan dengan analisis deskriptif kuantitatif dan deskriptif kualitatif. Hasil menunjukkan bahwa wisatawan backpacker melakukan pola perjalanan intra-destinasi, yaitu melakukan perjalanan di Bali, dominan mengunjungi Ubud dengan rata-rata lama menginap 6 hari, sebagian besar melakukan pola perjalanan intra-destinasi yakni Ubud-Uluwatu-Canggu, dengan Kuta sebagai daerah tujuan wisata pertama yang dikunjungi di Bali. Pola perjalanan inter-destinasi, yaitu perjalanan antar destinasi yang ada di Indonesia, sebagian besar wisatawan backpacker berkunjung ke Gili Island dengan rata-rata lama menginap 5 hari, dominan melakukan pola perjalanan inter-destinasi yakni Gili Island-Bali, dengan Bali sebagai destinasi wisata pertama yang dikunjungi. Pola intra-regional yaitu perjalanan yang dilakukan di negara-negara Asia Tenggara, Thailand menjadi negara di Asia Tenggara yang paling banyak dikunjungi oleh wisatawan backpacker selain Indonesia, dominan melakukan pola perjalanan intra-regional yakni Thailand-Cambodia-Vietnam-Indonesia, dan Indonesia sebagai destinasi pertama yang dikunjungi. Pola perjalanan wisatawan backpacker jika ditinjau dari pola inter-regional, wisatawan backpacker juga mengunjungi kawasan Negara yang lain selain kawasan Negara Asia Tenggara, dan dominan mengunjungi Australia dengan rata-rata lama menginap selama 91 hari, serta melakukan pola perjalanan inter-regional yakni Australia-ASEAN.

Keywords: backpacker tourist, canggu, travel pattern. 


\section{PENDAHULUAN}

Pada zaman modern seperti dewasa ini, manusia melakukan perjalanan dengan tujuan untuk berwisata atau memperoleh kesenangan, berbeda dengan zaman dahulu ketika orang melakukan perjalanan untuk memperoleh makanan dan tempat tinggal yang aman. Wisata adalah perjalanan yang dilakukan oleh seseorang atau kelompok orang dengan mengunjungi tempat tertentu untuk tujuan rekreasi, pengembangan pribadi, atau mempelajari daya tarik wisata yang dikunjunginya dalam jangka waktu sementara (Menurut UU Nomor 10 Tahun 2009). Pariwisata kini menjadi suatu kebutuhan semua orang di dunia, berbagai macam tipologi wisatawan di dunia pun ditemukan. Cohen (1972) mengklasifikasikan wisatawan menjadi 4 jenis, antara lain individual mass organized mass tourist, drifter dan explorer. Wisatawan explorer merupakan wisatawan yang melakukan perjalanan dengan mengatur perjalanannya sendiri, dan tidak mau mengikuti jalan-jalan wisata yang sudah umum melainkan mencari hal yang tidak umum. (Cohen, 1972 dalam Suwena \& Widyatmaja (2017)).

Perkembangan teknologi informasi yang semakin pesat menyebabkan perencanaan perjalanan wisata tidak harus mengandalkan jasa perjalanan wisata, melainkan kini wisatawan dapat mengatur dan merencanakan perjalanan wisatanya sendiri melalui online travel agent (OTA) atau e-commerce yang merupakan wadah atau situs online memuat tentang seluruh informasi mulai dari atraksi wisata, pemesanan akomodasi, pemesanan transportasi dan lain-lain. Hal tersebut menyebabkan adanya tren wisata backpacker, yang merupakan tipe wisatawan explorer dan melakukan aktivitas pariwisata dengan dana terbatas serta mengandalkan fasilitas-fasilitas berstandar lokal (Suwena \& Widyatmaja, 2017). Tren wisata backpacker ini sangat berkembang di seluruh dunia, tak terkecuali Indonesia yang memiliki beranekaragam atraksi wisata alam \& budaya yang tersebar di setiap pulaunya. Pulau Bali sebagai salah satu pulau di Indonesia yang memiliki keindahan panorama alam dan budaya, adat-istiadat yang unik dan beragam menjadi daya tarik wisatawan backpacker untuk datang dan berkunjung. Terdapat 2 kampung backpacker di Bali yaitu di kawasan Poppies Lane Kuta dan kawasan Monkey Forest Ubud menurut Virgies Travel Guide dalam siaran Metro TV. Selain kawasan Ubud dan Kuta yang merupakan kampung backpacker utama yang ada di Provinsi Bali, namun adapun kawasan baru yang banyak dikunjungi wisatawan backpacker di Bali yaitu kawasan Canggu. Canggu mulai berkembang menjadi daya tarik wisata baru yang banyak dikunjungi oleh wisatawan backpacker ditandai dengan banyaknya jumlah hostel yang ada, lebih dari 30 hostel dan dipasarkan melalui salah satu situs pemesanan hostel terbesar di dunia yaitu Hostelworld. Hal ini terjadi karena Canggu merupakan kawasan wisata yang menawarkan keindahan pantai dan sekaligus suasana pedesaan serta sawah yang masih terjaga. Menurut artikel a Broken Backpack, Canggu juga menjadi salah satu destinasi favorit bagi wisatawan backpacker dan aktivitas wisata yang biasa dilakukan adalah berselancar, berpesta, meditasi dan yoga. Wisatawan backpacker merupakan wisatawan aktif yang artinya ingin mengunjungi tempat-tempat wisata baru setiap harinya selama perjalanannya.

Menuh (2016) melakukan studi mengenai karakteristik dan dampak wisatawan backpacker yang berkunjung ke Kuta menemukan karakteristik wisatawan backpacker yaitu sebagian besar wisatawan backpacker berasal dari Benua Eropa dengan persentase sebesar 59\%. Berdasarkan usia, wisatawan backpacker didominasi wisatawan berusia muda. Wisatawan backpacker memiliki lama berkunjung di Bali 8-15 hari. Menurut Welk (2004) terdapat lima pilar idiologi perjalanan wisata backpacker yaitu (1)perjalanan dengan budget rendah, (2)perjalanan untuk bertemu dengan orang yang berbeda, (3)ingin bebas dan open minded, (4)untuk mengatur perjalanan secara bebas dan mandiri, (5)perjalanan dilakukan sejauh mungkin. Andriyani dan Hadi (2018) dalam studinya mengidentifikasi pola perjalanan wisatawan Timur Tengah yang berkunjung ke Bandung menggunakan pola pergerakan menurut Lau \& McKercher (2006) yang terdiri dari 5 pola yaitu single point, base site, stopover, chaining loop, destination region loop, complex neighborhood. Hasil menunjukkan bahwa karakteristik wisatawan 
FIT asal Timur Tengah yang dijadikan informan adalah wisatawan near psychocentric dan mendekati mid-centric karena cenderung mengunjungi daya tarik wisata yang umum dan sudah populer di Bandung seperti Kawah Putih, Air Terjun Cimahi, Tangkuban Perahu, Floating Market dan tempat wisata popular lainnya di Bandung. Sedangkan pola pergerakan yang terbentuk adalah pola destination region loop. Persamaan dengan studi ini adalah variabel yang diteliti yaitu pola perjalanan, namun perbedaanya yakni studi yang dilakukan oleh penulis berjudul karakteristik dan pola perjalanan wisatawan backpacker yang menginap di Canggu. Bentuk-bentuk atau pola pergerakan wisatawan ini berdasarkan karakteristik ruang baik dalam tingkat atau cakupan yang lebih luas terdiri dari pergerakan wisatawan antar destinasi di wilayah atau daerah berbeda (inter-destination), ataupun dalam tingkat atau cakupan yang lebih sempit, pergerakan tersebut terbentuk dari pergerakan antar atraksi wisata di sebuah destinasi (intradestination), pergerakan antar negara di satu kawasan (intra-regional), serta pergerakan wisatawan antar kawasan negara (interregional) (Andriyani \& Hadi, 2018). Melihat potensi Canggu sebagai daerah tujuan wisata baru yang dikunjungi oleh wisatawan backpacker selain dua kantong backpacker yang sudah ada di Bali yakni Kuta dan Ubud, maka dari itu studi ini dilakukan untuk mengetahui karakteristik dan pola perjalanan wisatawan backpacker yang menginap di Canggu.

\section{METODE PENELITIAN}

Desa Canggu yang terletak di Kecamatan Kuta Utara menjadi lokasi studi. Data dikumpulkan melalui penyebaran kuesioner kepada responden wisatawan backpacker yang menginap di Canggu untuk mengetahui karakteristik wisatawan backpacker yang ditinjau dari moda transportasi yang digunakan, rata-rata pengeluaran per hari, jenis kelamin, status, tingkat pendidikan, pekerjaan, aktivitas yang dilakukan selama di Canggu dan di Bali serta pola perjalanan yang ditinjau dari pola intradestinasi, inter-destinasi, inter-regional dan intra-regional. Bentuk kuesioner ini berupa tipe pilihan dimana responden bisa memilih jawaban dari beberapa pilihan yang telah disediakan. Teknik penentuan sampel yang digunakan adalah purposive sampling yang merupakan teknik penentuan sampel dengan pertimbangan tertentu yang dianggap paling tahu tentang apa yang diharapkan, dalam studi ini yaitu wisatawan backpacker yang menginap di Canggu. Teknik penentuan jumlah sampel digunakan teknik quota sampling yang merupakan teknik pengambilan sampel dengan menetapkan jumlah subjek (jatah) yang akan diteliti (Sutrisno Hadi,2007). Sebanyak 33 hostel yang ada di Canggu dijadikan sampel studi, serta menjatahkan 4 responden di setiap hostelnya. Penulis menjatahkan 4 responden atas dasar pertimbangan bahwa rata-rata hostel di Canggu memiliki minimal kapasitas hunian kamar sebanyak 4 orang atau 4 beds. Jadi total jumlah responden adalah 132 responden. Teknik aanalisis data yang digunakan yaitu analisis deskriptif kuantitatif untuk menggambarkan karakteristik dan analisis deskriptif kualitatatif untuk menjelaskan pola perjalanan wisatawan backpacker yang menginap di Canggu.

\section{HASIL DAN PEMBAHASAN}

\section{Karakteristik Wisatawan Backpacker yang Menginap di Sentra Pariwisata Canggu}

Karakteristik wisatawan backpacker yang menginap di Canggu berdasarkan jenis kelamin, sebagian besar merupakan wisatawan backpacker yang berjenis kelamin laki-laki dengan jumlah 71 orang (53\%). Hasil ini menunjukkan hasil yang berbeda dengan penemuan oleh Menuh (2015) bahwa wisatawan backpacker yang berkunjung ke Kuta sebagian besar adalah wanita. Ditinjau dari status perkawinan, hampir seluruh responden merupakan wisatawan yang belum menikah sebesar 94\%. Hal ini sesuai dengan hasil dari Dayour et al (2013) juga menunjukkan bahwa wisatawan backpacker yang berkunjung ke Cape Coast-Elmina, Ghana didominasi oleh wisatawan yang belum menikah yaitu sebesar 84\%. Berdasarkan tingkat pendidikan, menunjukkan sebagian besar wisatawan backpacker memiliki tingkat pendidikan "S1" sejumlah 69 orang (52\%). Hasil ini menunjukkan hasil yang sama dengan studi yang dilakukan oleh Supattra (2017) bahwa 49,6\% wisatawan backpacker yang berkunjung ke Thailand merupakan wisatawan dengan tingkat pendidikan "S1" 
atau undergraduate degree. Wisatawan backpacker yang menginap di Canggu didominasi oleh wisatawan yang bekerja sebagai karyawan $(38 \%)$, pelajar $(27 \%)$, dan $26 \%$ diantaranya tidak bekerja. Hasil tersebut berbeda dengan studi yang dilakukan oleh Darmawan (2018) bahwa wisatawan backpacker yang berkunjung ke Ubud didominasi oleh pelajar sebesar $38 \%$. Wisatawan backpacker sebagian besar berusia diantara 15-24 tahun yaitu sejumlah 77 orang (58\%). Bencsik, Csikos, dan Juhez (2016) menyatakan generasi $\mathrm{Z}$ adalah orang-orang yang lahir dalam rentang tahun 1995-2010, maka dari itu, disimpulkan sebagian besar wisatawan backpacker yang berusia 15-24 tahun atau lahir pada tahun 1995-2004 merupakan wisatawan yang termasuk dalam kelompok generasi $\mathrm{Z}$. Generasi $\mathrm{Z}$ disebut juga iGeneration atau generasi internet. Karakteristik wisatawan backpacker ditinjau dari negara asal, didapat hasil sebesar $72 \%$ atau 95 orang dari 132 wisatawan berasal dari negara-negara di Benua Eropa yang terdiri dari Inggris, Jerman, Belanda, Belgia, dan negaranegara di Eropa lainnya. Hasil studi ini sesuai dengan studi yang dilakukan oleh Menuh (2016) juga menunjukkan wisatawan backpacker yang menginap di Kuta merupakan wisatawan yang berasal dari Benua Eropa. Ditinjau dari lama menginap, rata-rata wisatawan backpacker menginap selama 9 hari di Canggu, sedangkan Darmawan (2018) menyebutkan rata-rata wisatawan backpacker menginap di Ubud selama 7 hari. Hal ini menunjukkan bahwa rata-rata lama menginap di Canggu lebih lama dibandingkan rata-rata lama menginap di Ubud. Hal ini dikarenakan Canggu merupakan tempat yang strategis, berdasarkan hasil wawancara dengan responden yang bernama Cameron, berusia 23 tahun berasal dari negara Inggris mengatakan bahwa Canggu merupakan daerah yang dekat dengan banyak tempat-tempat wisata lainnya yang beragam mulai dari pantai, sawah, serta didukung dengan ketersediaan fasilitas yang nyaman, lengkap dan terjangkau mulai dari akomodasi, restoran, transportasi. Dan banyak aktivitas wisata yang dapat dilakukan di Canggu seperti surfing atau berselancar di pantai-pantai yang ada di Canggu. Lama menginap di Bali yaitu rata-rata selama 21 hari, jika dibandingkan dengan wisatawan FIT (Free Individual Traveler), wisatawan backpacker memiliki rata-rata lama menginap yang lebih lama daripada wisatawan FIT, hal ini dibuktikan dalam studi yang dilakukan Lau \& Mckercher (2006) bahwa wisatawan FIT yang berkunjung ke Hongkong memiliki ratarata lama menginap selama 4,6 malam atau kurang dari 1 minggu. Sebagian besar wisatawan backpacker di Canggu melakukan aktivitas sightseeing yaitu sebanyak 106 orang (80\%), hasil tersebut sesuai dengan hasil studi Darmawan (2018) bahwa wisatawan backpacker yang menginap di Ubud sebagian besar memiliki aktivititas sightseeing dengan jumlah 35 orang (27\%). Aktivitas sightseeing ini merupakan aktivitas mengunjungi tempattempat wisata yang ada di Canggu seperti Pantai Batu Bolong, Pantai Batu Mejan (Echo Beach), Pantai Canggu, Pantai Berawa serta area persawahan yang masih asri di Canggu. Kemudian disusul oleh aktivtitas shopping atau wisata belanja sejumlah 75 orang (57\%). Selain keindahan panorama pantainya, Canggu juga terkenal dengan wisata kuliner dan belanjanya. Di Canggu banyak terdapat café serta restaurant, toko pakaian dan butik yang bergaya hypster atau unik dan berbeda dari zaman. Canggu terletak di kawasan pesisir, sehingga banyak terdapat pantai-pantai yang indah dan memiliki keunikan tersendiri. Tidak hanya untuk menikmati keindahan panorama matahari terbenam (sunset), 36\% wisatawan backpacker atau sejumlah 47 orang melakukan wisata selancar (surfing) di Canggu. Sehingga di Canggu banyak terdapat sekolah berselancar untuk para wisatawan yang ingin belajar selancar seperti Canggu Surfing School, In Da Surf Camp \& School Canggu, Bali Local Surf School. Kemudian aktivitas yang dilakukan selama di Bali adalah sport activities (92\%), taking pictures (79\%), learning Balinese cultural and historical things (62\%). Hasil persentase melebihi angka $100 \%$ dikarenakan responden memilih lebih dari satu jawaban yang tertera pada pilihan aktivitas selama di Canggu dan Bali secara keseluruhan. Ditinjau dari teman perjalanan, sebanyak 83 orang atau setara dengan 63\% wisatawan backpacker bepergian sendiri (solo traveler) tanpa mengajak pendamping, wisatawan backpacker cenderung menggunakan moda transportasi sepeda motor sebesar $75 \%$ atau 100 orang wisatawan memilih sepeda motor sebagai moda transportasinya selama di Canggu. Hal ini terjadi karena di Canggu terdapat banyak 
tempat penyewaan sepeda motor dengan harga mulai dari Rp.50.000-70.000 per hari, sehingga wisatawan backpacker dapat bepergian dengan mudah dan cepat. Sebesar 92\% wisatawan backpacker memesan kamar hostel melalui online booking atau pemesanan akomodasi hostel via internet seperti pada situs Hostelworld.com, Booking.com, Agoda dan lain-lain. Berdasarkan pengorganisasian perjalanannya menunjukkan bahwa hampir seluruh wisatawan backpacker yang menginap di Canggu mengorganisasikan perjalanannya sendiri dengan frekuensi 128 orang (97\%), hasil ini sesuai dengan salah satu pilar dari lima pilar ideologi perjalanan wisata backpacker menurut Welk (2004) yaitu "untuk mengatur perjalanan secara bebas dan mandiri". Sebesar $40 \%$ wisatawan yang melakukan perjalanannya pada waktu cuti kerja yang diberikan oleh perusahaan. Wisatawan backpacker selama menginap di Canggu sebagian besar (77\%) memilih restoran lokal yang ada di Canggu dan sebesar $65 \%$ wisatawan juga memilih warung lokal. Hasil tersebut sesuai dengan studi yang dilakukan oleh Rodriguez (2011) yang menyebutkan salah satu karaktersitik backpacker secara umum yaitu keinginan untuk bertemu dan berinteraksi dengan orangorang lokal. Dengan bertemu orang-orang lokal dan mengenal budaya baru, backpacker dapat memperoleh kenangan dan pengalaman yang baru merupakan salah satu motif utama backpacker melakukan perjalanan. Berdasarkan rata-rata pengeluaran per hari selama menginap di Canggu, wisatawan backpacker rata-rata mengeluarkan uang sejumlah Rp. 262.000 untuk makanan dan minuman, pengeluaran tersebut berbeda dengan hasil studi Menuh (2016) yang menunjukkan bahwa wisatawan backpacker di Kuta menghabiskan sejumlah Rp. 192.849 per hari untuk makanan dan minuman. Berselisih Rp.69.151, wisatawan backpacker di Canggu mengeluarkan uang lebih banyak daripada wisatawan backpacker yang menginap di Kuta. Hal ini dikarenakan wisatawan backpacker selama menginap di Canggu sebagian besar (77\%) memilih restoran lokal yang ada di Canggu dan sebesar 65\% wisatawan juga memilih warung lokal. Untuk akomodasi wisatawan backpacker mengeluarkan sejumlah Rp.140.000, hasil ini hampir menyerupai hasil studi Menuh (2016) yang menunjukkan bahwa untuk akomodasi hostel per harinya wisatawan backpacker Kuta mengeluarkan uang sejumlah Rp.142.737. Untuk transportasi, wisatawan backpacker menghabiskan sejumlah Rp. 66.000 per hari dikarenakan wisatawan backpacker yang menginap di Canggu sebagian besar menggunakan moda transportasi sepeda motor, harga sewa sepeda motor berkisar antara Rp.50.000-Rp.70.000/ hari, tergantung dari jenis sepeda motor yang disewa. Sebagian besar $(65 \%)$ diantaranya merupakan wisatawan backpacker yang pertama kali (first timer) berkunjung ke Canggu. Hasil ini mengungkapkan bahwa wisatawan backpacker termasuk dalam klasifikasi wisatawan explorer menurut teori yang dikemukakan oleh Smith (1977) mengenai klasifikasi wisatawan yakni wisatawan explorer adalah wisatawan yang mencari perjalanan baru, serta teori yang diungkapkan oleh Plog (1972) bahwa wisatawan backpacker termasuk dalam klasifikasi wisatawan allocentric yaitu wisatawan yang ingin mengunjungi tempattempat yang belum diketahui, dan bersifat petualangan (adventure). Ditinjau dari kunjungan ke Bali, $60 \%$ diantaranya merupakan wisatawan backpacker first timer. Hasil tersebut sesuai dengan hasil studi oleh Rodriguez (2011) yang menyatakan bahwa karakteristik wisatawan backpacker adalah wisatawan aktif, dengan mencari sesuatu yang baru setiap hari selama perjalanannya. Berbeda halnya dengan studi yang dilakukan oleh Lau \& McKercher (2006) pada wisatawan FIT (Free Individual Traveler) yang berkunjung ke Hongkong menyatakan bahwa sebagian besar (53\%) merupakan wisatawan repeater. Kedua hasil tersebut membuktikan bahwa terdapat perbedaan karakteristik diantara wisatawan backpacker dan wisatawan FIT. Dalam mengakses informasi pariwisata, $75 \%$ wisatawan backpacker memilih untuk bertanya kepada masyarakat lokal, tepatnya masyarakat lokal Canggu yang menjadi pegawai hostel tempat wisatawan tersebut menginap. Wisatawan backpacker yang menginap di sentra pariwisata Canggu mendapatkan informasi tentang Canggu melalui internet sebesar $82 \%$. Hasil tersebut memperkuat fakta bahwa karakteristik wisatawan backpacker yang merupakan generasi $\mathrm{Z}$ sebagaimana diketahui bahwa karakteristik wisatawan backpacker 
ditinjau dari usia yakni berusia diantara 15-24 tahun, bahwa generasi $\mathrm{Z}$ memiliki karakteristik yaitu segala aktivitas yang dilakukan dominan berhubungan dengan internet. Wisatawan memilih lebih dari satu pilihan jawaban sehingga total persentase keseluruhan melebihi $100 \%$.

\section{Pola Perjalanan Wisatawan Backpacker yang Menginap di Sentra Pariwisata Canggu}

Wisatawan backpacker yang menginap di sentra pariwisata Canggu melakukan beberapa pola perjalanan diantaranya dari pola perjalanan intra-destinasi yaitu perjalanan wisatawan selama di Bali, kemudian pola perjalanan inter-destinasi yaitu perjalanan wisatawan antar destinasi yang ada di Indonesia, serta pola perjalanan intra-regional yang merupakan perjalanan wisatawan dalam satu kawasan regional yaitu di negara-negara Asia Tenggara (ASEAN) dan pola perjalanan inter-regional yaitu perjalanan wisatawan antar kawasan regional seperti kawasan Asia Timur, Asia Barat, Eropa , Australia, Amerika dan lain-lain.

Ditinjau dari pola perjalanan intradestinasi, selain Canggu, daya tarik wisata yang paling banyak dikunjungi wisatawan backpacker selama berkunjung ke Bali adalah Ubud sejumlah 102 orang, kemudian disusul oleh Seminyak sejumlah 69 orang, Nusa Penida sejumlah 64 orang, Kuta sejumlah 61 orang, dan Uluwatu sejumlah 35 orang. Hasil ini membuktikan bahwa Ubud dan Kuta memang menjadi kampung backpacker berdasarkan acara yang ditayangkan Metro TV berjudul Virgies Travel Guide, bahwa ada lima tempat yang dikategorikan sebagai kampung backpacker yaitu Poppies Lane Kuta, kawasan Monkey Forest Ubud, Sosrowijayan Jogja, Jalan Jaksa Jakarta, dan Prawirotaman Jogja. Berdasarkan rata-rata lama menginap di daya tarik wisata yang ada di Bali, didapat hasil bahwa wisatawan backpacker selain di Canggu, menginap paling lama di Ubud yaitu selama 6 hari. Hasil tersebut sesuai dengan hasil studi Darmawan (2018) yang menunjukkan bahwa sebagian besar wisatawan backpacker yang menginap di Ubud selama 3-7 hari. Hal tersebut terjadi karena wisatawan backpacker ingin belajar kebudayaan baru di Ubud sesuai dengan studi yang dilakukan oleh Darmawan (2018) yang mengungkapkan faktor yang mempengaruhi wisatawan backpacker menginap pada hostel di Ubud didominasi oleh faktor belajar kebudayaan baru, yang terdiri atas empat variabel yaitu: (1) belajar kebudayaan baru, (2) menikmati wisata budaya, (3) karena terdapat bangunan bersejarah, dan (4) menikmati wisata alam. Hasil menyatakan bahwa wisatawan backpacker dominan melakukan pola perjalanan intra-destinasi yakni UbudUluwatu-Canggu, dan Kuta sebagai daerah tujuan wisata yang pertama dikunjungi di Bali.

Ditinjau dari pergerakannya, wisatawan backpacker yang merupakan first timer berbeda pergerakannya dengan wisatawan repeater selama melakukan perjalanan wisata di Bali, hasil menunjukkan wisatawan backpacker yang pertama kali mengunjungi Bali (first timer) lebih banyak mengunjungi destinasi wisata yang ada di Bali yakni sebanyak 4 destinasi, sedangkan wisatawan backpacker yang sudah pernah mengunjungi Bali sebelumnya (repeater) cenderung mengunjungi destinasi lebih sedikit yaitu sejumlah 3 destinasi di Bali. Namun jika dilihat dari rata-rata lama menginap di setiap destinasi, wisatawan backpacker repeater cenderung menginap lebih lama dibandingkan dengan wisatawan first timer selama berwisata di Bali. Hasil ini membuktikan bahwa wisatawan backpacker melakukan perjalanan wisata yang dipengaruhi oleh familiarisasi destinasi menurut Tideswell dan Faulkner, 1999. Familiarisasi destinasi merupakan gabungan dari pengalaman perjalanan sebelumnya dengan tingkat informasi yang diperoleh tentang suatu destinasi, dan pola pegerakan wisatawan dipengaruhi oleh pengalaman pada kunjungan sebelumnya, terbukti bahwa wisatawan backpacker yang sudah pernah mengunjungi Bali sebelumnya, cenderung mengunjungi daerah tujuan wisata di Bali yang lebih sedikit daripada wisatawan first timer. Wisatawan backpacker yang pertama kali mengunjungi Bali lebih banyak mengunjungi daerah tujuan wisata yang ada di Bali namun dengan waktu yang relatif lebih singkat di setiap tempat wisata yang dikunjunginya. Hasil tersebut sesuai dengan hasil studi yang dilakukan oleh Gitelson dan Crompton, 1984; Oppermann, 1997; Lehto et al., 2004; Wang, 2004 yang menunjukkan bahwa wisatawan yang pertama kali berkunjung ke suatu destinasi cenderung 
memiliki kegiatan yang lebih bervariasi dari pada wisatawan repeater. Hal tersebut terjadi karena wisatawan repeater ingin lebih berelaksasi hanya pada beberapa daerah tujuan wisata yang dikunjungi di Bali dan menghabiskan waktu lebih lama di setiap daerah yang dikunjungi tersebut, diperkuat oleh pendapat wisatawan backpacker bernama Matthias asal Belanda yang berusia 22 tahun yang merupakan wisatawan repeater atau sudah pernah berkunjung ke Bali sebelumnya, menyatakan bahwa dia hanya ingin berelaksasi dan melepas penat serta menyegarkan pikiran kembali dengan berwisata di Bali pada kunjungan kedua kalinya ini.

Selain melakukan perjalanan intradestinasi, wisatawan backpacker juga melakukan perjalanan inter-destinasi yaitu mengunjungi destinasi-destinasi yang ada Indonesia. Selain Bali, Gili Island menjadi destinasi wisata yang paling banyak dikunjungi oleh wisatawan backpacker sejumlah 88 orang, kemudian disusul oleh Lombok dengan 45 orang, Pulau Jawa dengan 24 orang serta Pulau Komodo dengan jumlah 21 orang. Hasil juga menunjukkan bahwa ratarata lama menginap yang paling lama adalah Gili dan Lombok yaitu dengan rata-rata menginap selama 5 hari. Hal ini terjadi karena di Gili Trawangan, Gili Meno dan Gili Air serta Lombok terdapat banyak aktivitas yang dapat dilakukan oleh wisatawan backpacker seperti sport activities diantaranya adalah snorkeling, diving, menikmati keindahan pantai dan mempelajari budaya-budaya yang unik dan menarik di Nusa Tenggara Barat. Sedangkan di Pulau Jawa wisatawan backpacker memiliki rata-rata menginap selama 6 hari. Hal ini dikarenakan Pulau Jawa memiliki 3 kampung backpacker yang lebih tepatnya berada di Sosrowijayan (Yogyakarta), Jalan Jaksa (Daerah Khusus Ibu Kota Jakarta), Prawirotaman (Yogyakarta) menurut Virgies Travel Guide, Metro TV. Wisatawan backpacker cenderung melakukan pola perjalanan inter-destinasi yakni Gili IslandBali, dan Bali sebagai destinasi pertama yang dikunjungi di Indonesia.

Ditinjau dari pola perjalanan intraregional, selain Indonesia, Negara yang paling banyak dikunjungi wisatawan backpacker adalah Thailand yaitu sejumlah 60 orang, disusul oleh Vietnam sejumlah 54 orang, Singapura sejulah 52 orang, Malaysia sejumlah 43 orang dan Kamboja sejumlah 39 orang. Hasil ini sesuai dengan studi yang dilakukan oleh Hampton \& Hamzah (2016) yang menyebutkan bahwa pada tahun 1990 an, perjalanan backpacker di Asia Tenggara di mulai dari Bangkok, Thailand kemudian menuju Penang, Malaysia menggunakan transportasi umum seperti bus atau minibus, lalu dari Penang, Malaysia menuju Sumatera, Indonesia menggunakan kapal feri melewati Selat Malaka, kemudian melewati jalan yang ada di Sumatera, umumnya melewati Danau Toba dan Bukittinggi. Perjalanan tersebut dilakukan baik itu sebelum menuju Singapura atau perjalanan menuju Jawa melewati Yogyakarta kemudian ke Bali dan Indonesia Bagian Timur seperti Gili, Lombok, Komodo dan Flores. Rute tersebut juga merupakan panduan dari buku yang berjudul Lonely Planet Guide Book. Ditinjau dari rata-rata lama menginap, di dalam pola perjalanan intra-regional, wisatawan backpacker menginap paling lama di Thailand yaitu dengan rata-rata selama 31 , hari. Hasil ini sesuai dengan hasil studi Hampton dan Hamzah (2016) yang juga menunjukkan bahwa wisatawan backpacker menghabiskan waktu selama lebih dari 30 hari di Thailand. Selanjutnya, Indonesia menjadi Negara ke-dua yang menjadi tempat wisatawan backpacker menghabiskan waktunya dengan rata-rata menginap selama 28 hari. Hal tersebut terjadi dikarenakan Indonesia dan Thailand memberlakukan visa exemption atau bebas visa kunjungan kepada negara-negara tertentu. Berdasarkan Peraturan Presiden Republik Indonesia Nomor 21 Tahun 2016 Tentang Bebas Visa Kunjungan, Indonesia memberikan bebas visa kepada 169 Negara, sedangkan Thailand memberlakukan bebas visa kunjungan kepada 48 Negara (www.thaiembassy.com). Beberapa diantara negara-negara di dunia yang menjadi sasaran bebas visa kunjungan oleh kedua negara tersebut merupakan negara-negara di Benua Eropa seperti Inggris, Jerman, Belanda, Belgia yang merupakan negara asal dari sebagian besar $(75 \%)$ wisatawan backpacker dalam penelitian ini. Sesuai dengan Peraturan Presiden RI No.21 Tahun 2016 pasal 4 yang menyatakan bahwa bebas visa kunjungan tersebut berlaku selama 30 hari dan tidak dapat diperpanjang atau diubah ke bentuk visa lainnya, sedangkan kebijakan bebas visa 
kunjungan di Thailand menyebutkan bahwa visa tersebut berlaku 30 hari jika masuk melalui jalur bandara internasional dan berlaku 15 hari jika masuk melalui jalur darat serta visa tidak dapat diperpanjang (www.thaiembassy.com). Dengan adanya bebas visa kunjungan berlaku 15 hari jika masuk melalui jalur darat menyebabkan wisatawan backpacker dapat memperpanjang bebas visa kunjungannya ke Thailand dengan cara keluar dari Thailand dan mengunjungi negara-negara tetangga terdekat kemudian kembali ke Thailand melalui jalur darat sehingga mereka dapat tinggal lebih lama atau lebih dari 30 hari di Thailand tanpa dipungut biaya tambahan. Hal tersebut juga membuktikan bahwa wisatawan backpacker mengunjungi negara-negara tetangga yang jaraknya berdekatan dengan Thailand seperti Vietnam, Kamboja dan Malaysia. Wisatawan backpacker menghabiskan waktu lebih lama di Vietnam dengan rata-rata menginap selama 22 hari, dan hasil ini sedikit berbeda dengan hasil studi dari Hampton \& Hamzah (2016) yang menunjukkan bahwa di di Vietnam wisatawan backpacker menghabiskan waktu rata-rata selama 37 hari. Dalam hasil studi ini, wisatawan backpacker juga mengunjungi Kamboja dan Malaysia dan rata-rata menginap selama 13 hari. Hal tersebut memiliki persamaan hasil dengan Hampton dan Hamzah (2016) yang menunjukkan bahwa di Kamboja wisatawan backpacker rata-rata menginap selama 13 hari, namun di Malaysia wisatawan backpacker menginap rata-rata selama 28 hari. Sebagian besar melakukan pola perjalanan intra-regional yaitu ThailandCambodia-Vietnam-Indonesia, dan Indonesia sebagai destinasi pertama yang dikunjungi selama berkunjung ke Negara ASEAN.

Sedangkan jika ditinjau dari pola perjalanan inter-regional, wisatawan backpacker paling banyak mengunjungi Australia yaitu sejumlah 43 orang dengan ratarata menginap selama 91 hari atau lebih dari 3 bulan. Hasil ini sesuai dengan hasil studi yang dilakukan oleh Nagai et al (2018) yang menunjukkan bahwa wisatawan backpacker dari berbagai negara mengikuti program Australian WHM atau Working Holidays Maker yang berarti bahwa wisatawan dapat berlibur sambil bekerja di Australia, pekerjaan yang dimaksud seperti: memetik buah, memproses buah, industri agrikultur atau pertanian, pekerjaan konstruksi serta pekerjaan di industri pariwisata. Wisatawan yang dapat berpartisipasi adalah wisatawan dari negaranegara partner Australia yang berusia antara 18-30 tahun. Hal ini juga diperkuat oleh wisatawan backpacker yang dijadikan sebagai responden merupakan wisatawan yang sebagian besar berusia 15-24 tahun. Wisatawan backpacker cenderung melakukan pola perjalanan inter-regional dengan pola Australia-ASEAN, dengan kawasan ASEAN sebagai destinasi pertama yang dikunjungi.

\section{SIMPULAN DAN SARAN Simpulan}

Karakteristik wisatawan backpacker yang menginap di Canggu, jika ditinjau dari tourist descriptor, sebagian besar berjenis kelamin pria, belum menikah, dan memiliki tingkat pendidikan Sarjana (S1), dominan bekerja sebagai karyawan, berusia diantara 15-24 tahun, sebagian besar berasal dari negaranegara di Benua Eropa, kemudian rata-rata lama menginap di Canggu 9 hari, menginap di Bali rata-rata 21 hari, dan paling banyak melakukan aktivitas sightseeing, shopping dan surfing selama di Canggu, aktivitas yang paling banyak dilakukan di Bali yaitu sport activities, taking pictures, dan learning Balinese cultural \& historical things, didominasi oleh wisatawan yang melakukan perjalanan sendiri. Ditinjau dari trip descriptor, moda transportasi yang digunakan selama di Canggu yaitu didominasi oleh sepeda motor, sebagian besar melakukan pemesanan akomodasi melalui online booking dan mayoritas wisatawan backpacker mengorganisasikan perjalanannya sendiri, dominan berwisata pada waktu cuti bekerja atau annual leave, pengeluaran selama $\mathrm{di}$ Canggu yakni; untuk makanan dan minuman sebesar Rp.262.000 per hari, untuk akomodasi sebesar Rp.140.000 per malam, dan transportasi sebesar Rp.66.000 per hari, didominasi oleh wisatawan first timer atau pertama kali datang ke Canggu, begitu juga dengan kunjungan ke Bali, kemudian wisatawan backpacker cenderung memilih local restaurant dan local warung sebagai tempat makan, sebagian besar memilih ask local people sebagai sumber informasi wisata selama di Bali, dan dominan mendapatkan informasi mengenai Canggu dari internet dan teman. 
Wisatawan backpacker melakukan pola perjalanan intra-destinasi, yaitu melakukan perjalanan di Bali, didapat hasil bahwa, daerah tujuan wisata di Bali yang paling banyak dikunjungi adalah Ubud dengan rata-rata lama menginap 6 hari. Pola perjalanan wisatawan backpacker first timer ke Bali lebih banyak mengunjungi daerah tujuan wisata yang ada di Bali namun dengan waktu yang relative singkat, sedangkan wisatawan backpacker repeater ke Bali cenderung lebih sedikit mengunjungi daerah tujuan wisata namun lebih lama menghabiskan waktu di setiap daerahnya, dan melakukan pola perjalanan intra-destinasi dengan pola Ubud-UluwatuCanggu, serta Kuta sebagai dearah tujuan pertama yang dikunjungi. Pola perjalanan inter-destinasi, yaitu perjalanan antar destinasi yang ada di Indonesia, sebagian besar wisatawan backpacker berkunjung ke Gili dengan rata-rata lama menginap 5 hari, dominan melakukan pola perjalanan yakni Gili Island-Bali, dan Bali sebagai destinasi pertama yang dikunjungi. Pola intra-regional yaitu perjalanan yang dilakukan di negara-negara Asia Tenggara, Thailand menjadi negara di Asia Tenggara yang paling banyak dikunjungi oleh wisatawan backpacker selain Indonesia, dengan rata-rata menginap selama 31 hari, dan sebagian besar melakukan pola perjalanan yakni Thailand-Cambodia-Vietnam-Indonesia, dan Indonesia sebagai destinasi pertama yang dikunjungi di ASEAN. Pola perjalanan wisatawan backpacker jika ditinjau dari pola inter-regional, wisatawan backpacker juga mengunjungi kawasan Negara yang lain selain kawasan Negara Asia Tenggara, dan dominan mengunjungi Australia dengan rata-rata lama menginap selama 91 hari, dominan melakukan perjalanan dengan pola Australia-ASEAN, dan ASEAN sebagai destinasi pertama yang dikunjungi.

\section{Saran}

Pola perjalanan wisatawan backpacker selama di Bali (intra-destinasi), dominan hanya berkunjung ke daerah Bali Selatan, dan tidak ditemukan wisatawan backpacker yang mengunjungi Candidasa dan Pemuteran dalam studi ini, maka dari itu pemerintah disarankan untuk lebih mempromosikan daerah-daerah yang berpotensi untuk dikunjungi wisatawan backpacker sehingga terwujud pemerataan pengembangan pariwisata guna meningkatkan perekonomian masyarakat Bali secara merata. Menurut pendapat wisatawan backpacker yang menginap di Canggu bahwa pentingnya keamanan untuk pengendara sepeda motor dan para pejalan kaki, sehingga disarankan untuk pemerintah beserta masyarakat Canggu khususnya agar memberikan pengawasan yang ketat kepada wisatawan yang ingin berkendara menggunakan sepeda motor serta pembenahan trotoar atau jalur pejalan kaki sehingga terhindar dari kecelakaan lalu lintas. 


\section{Kepustakaan}

Anonim. 2009. Undang-Undang Republik Indonesia Nomor 10 Tahun 2009 Tentang Kepariwisataan.

2016.Peraturan Presiden Republik Indonesia Nomor 21 Tahun 2016 Tentang Bebas Visa Kunjungan.

Andriani, N.N., Hadi, A.P. 2018. Pola Perjalanan Wisatawan Timur Tengah Berdasarkan Profil Wisatawan Dan Motivasi Pola Pergerakan Di Bandung. Proceeding: National Conference Of Creative Industry Universitas Bunda Mulia, Jakarta, 5-6 September 2018. pp 1-77. Indonesia.

Darmawan, I.P.E. 2018. "Faktor-Faktor Yang Mempengaruhi Keputusan Wisatawan Backpacker Menginap pada Hostel di Ubud". Unpublish Bachelor Thesis. Program Sarjana di Fakultas Pariwisata: Industri Perjalanan Wisata Universitas Udayana.

Hampton, M.P., Hamzah, A. 2016. Change, Choice and Commercialization: Backpacker Routes in Southeast Asia. Journal of Urban and Regional Policy. Vol 47/4. pp 556-571. Willey Online Library.

Lau, G., Mckercher, B. 2006. Understanding Tourist Movement Patterns In a Destination: A GIS Approach. Tourism and Hospitality Research. Vol 7/1. pp 3949. SAGE Publishing.

Lew, A., Mckercher, B. 2006. Modelling Tourist Movement: A Local Destination Analysis. Annals of Tourism Research. Vol 33/2. pp 403-423. Research Gate.

Lue, C. C., Crompton, J. L. and Fesenmaier, D. R. 1993. Conceptualization of Multidestination Pleasure Trips. Annals of Tourism Research. Vol 20. pp 289-301. Pergamon Press. 
Menuh. 2016. Karakteristik Wisatawan Backpacker dan Dampaknya terhadap Pariwisata Kuta, Bali. Jurnal Master Pariwisata. Vol 2/2. pp 177-188.

Nirwandar, Sapta. 2017. Tren Pariwisata 2018 diakses dan diunduh melalui https://nasional.sindonews.com/read/1266 733/18/tren-pariwisata-2018-1513589619 pada tanggal 1 Maret 2019 pukul 15.00 Wita.

Oppermann, M. 1997. First-Time and Repeat Visitors to New Zealand. Tourism Management, 18, 3, 177-181.

Pearce, P. (1990). The Backpacker Phenomenon : Preliminary Answer to Basic Questions. Townsville : Departement of Tourism, James Cook University.

Rodriguez, R. 2011. Backpacking Tourism in Tampere. Tampere: Tampere University of Applied Sciences.
Saldanha, A. 2002. Music Tourism And Factions Of Bodies In Goa. United Kingdom : Open University.

Seaton, A.V. dan M.M. Bennett. 1996. The Marketing of Tourism Product: Concepts, Issues, and Cases. London: International Thomson Business Press.

Suwena, I Ketut dan I Gst Ngr Widyatmaja. 2017. Pengetahuan Dasar Ilmu Pariwisata. Denpasar : Pustaka Larasan.

Visa Extemption Rule Diakses dan diunduh melalui www.thaiembassy.com__ Pada tanggal 30 Agst 2019 pukul 22.00 Wita

Vukica et al. 2013. The Presence of Backpacking Tourism in Europe. Serbia: University of Novi Sad.

Yoeti. 1983. Pengantar Ilmu Pariwisata. Bandung : Angkasa. 